\title{
$\begin{array}{llllllll}\mathrm{A} & \mathrm{R} & \mathrm{T} & \mathrm{I} & \mathrm{C} & \mathrm{L} & \mathrm{E} & \mathrm{S}\end{array}$
}

\section{A SERVICE PERSPECTIVE FOR HUMAN CAPITAL RESOURCES: A CRITICAL BASE FOR STRATEGY IMPLEMENTATION}

\author{
CHARLES R. GREER \\ Texas Christian University \\ ROBERT F. LUSCH \\ University of Arizona \\ MICHAEL A. HITT
}

Texas A\&M University and Texas Christian University

\begin{abstract}
Although strategy formulation has received the lion's share of attention in strategic management research, strategy implementation is widely considered to provide the greatest challenges for top executives. Observers have cited the need for more research on implementation, and thought leaders have called for the use of interdisciplinary approaches. Thus, we explore strategy implementation from the perspective of relational capital and human capital resources (in which relationships are especially important) and the development, bundling, and deployment of these resources to create strategic capabilities. Our discussion of implementation is unique in that we explain how it can be improved when guided by service-dominant logic (SDL) from the marketing field. We show how the emphasis of SDL on the exchange of service (rather than transactional interactions) and the manifestations of a service perspective-such as enduring relationships, collaboration, co-creation, open dialogue, trust, and status minimization - can facilitate the bundling and deployment of human capital resources for effective strategy implementation. We explain how SDL can facilitate implementation in the context of interdependencies, business ecosystems, and interactions across organizational boundaries. We provide both propositions and suggestions for future research.
\end{abstract}

Top executives are responsible for determining the strategic vision and direction of the firm. Thus, they must develop an effective strategy, one that helps their firm gain and maintain a competitive advantage and enhance shareholder wealth. However, an excellent strategy is of little value unless it is effectively implemented. Interestingly, Hrebiniak (2005) argued that implementing a strategy effectively is more difficult than developing a good strategy. In fact, reports from several top executives revealed that their most

The authors contributed equally to this manuscript. We would like to acknowledge Kevin Mossholder, Richard Priem, Rhett Brymer, Dan Wren, and the late Mike Harvey for their helpful comments on earlier versions of this paper. challenging concern is strategy implementation (most executives refer to it as execution) (Barrows, 2014; Knowledge@Wharton, 2005). Several prerequisites must be met to achieve successful implementation of a firm's strategy.

It has been argued that to implement a firm's strategy, the top management team must engage managers throughout the organization. Moreover, the implementation process is multilevel (from top to bottom of the hierarchy) and multiunit (across all units of the organization) (Mistry, Barrick, Kirkman, \& Hitt, 2016), requiring the effective use of internal relational capital among managers within and across levels. Essentially, top-, middle-, and lower-level managers must take actions to implement the firm's strategy. Further, Becker and Huselid (2006) argued 
that a firm's strategy is implemented through its human capital. Thus, managerial actions to successfully implement strategy require the firm's human capital to effectively accomplish tasks designed to achieve implementation goals. The purpose of this work is to extend the work of Becker and Huselid (2006) by explaining how human capital can be managed to best implement the firm's strategy.

Surprisingly, despite its importance there has been relatively little scholarly work on strategy implementation, and researchers have argued that the intricacies of strategy-implementation processes have been misunderstood (Martin \& Eisenhardt, 2010). This lack of knowledge is critical as senior executives report that on average their firms achieve only $63 \%$ of the results expected from strategic plans (Knowledge@Wharton, 2005). And, given the importance of human resources to effective implementation, research is needed to help us understand how human capital can be best managed to achieve the firm's implementation goals. Yet despite numerous studies on the alignment of human resource (HR) systems and practices with business strategies, there has been little analysis done on the role of strategic human resource management (SHRM) in strategy implementation (Becker \& Huselid, 2006). We argue that management of human capital, which serves as the touchstone or raison d'être for SHRM, has not been sufficiently studied, particularly given the multiplex nature of strategy implementation (multilevel and multiunit). Thus, we need to learn more about how the human capital foundations of SHRM, such as those residing in social complexity (context), influence strategy implementation because the firm's human capital is difficult to copy and is critically important in creating value (Coff \& Kryscynski, 2011). Such exploration can then serve to direct more research in this area.

In this article, we integrate a service perspective that has roots in the field of service management (Bowen \& Schneider, 2014; Gutek, Groth, \& Cherry, 2002) and service marketing (Berry, 2000; Cadwallader, Jarvis, Bitner, \& Ostrom, 2010; Gummesson, 2007). However, we also incorporate the more recent service-dominant logic (SDL) view from the field of marketing (Lusch \& Vargo, 2006, 2014; Vargo \& Lusch, 2004, 2016) and apply it to the management of relational and human capital resources (HCR). HCR is the "firm's portfolio of (aggregate) knowledge, skills, and abilities" (Haynes, Hitt, \& Campbell, 2015, p. 481) and has a major firmspecific component that is contingent on the strategy being implemented.
Application of SDL demonstrates the interdisciplinary nature of and contributes knowledge and understanding to strategy implementation. Our application of a service view and SDL from marketing also addresses the call for a more interdisciplinary approach to understanding the management of human capital (Nyberg \& Wright, 2015). Thus, this work describes how managers can more effectively manage human capital to successfully implement the firm's strategy. The key concepts of SDL are presented in Table 1 and the appendix.

We draw on the concept of service-dominant orientation (SDO) to provide a bridge between SDL and the strategic capabilities needed to enact this logic. SDO refers to a means by which managerial attention is directed to strategic capabilities (or the development of such capabilities). More specifically, SDO consists of six SDL-based capabilities that contribute to the implementation of strategy: concerted interaction (e.g., seamlessly working together), developmental interaction (e.g., educating, information sharing), empowered interaction (e.g., enabling customer or partner influence), ethical (e.g., non-opportunistic, not misleading) individuated interaction (e.g., process or contextual sensitivity), and relational (e.g., bonding, emotional linkage) capabilities (Karpen, Bove, \& Lukas, 2012; Karpen, Bove, Lukas, \& Zyphur, 2015). ${ }^{1}$ We integrate these throughout our discussions. The SDL literature maintains that SDO capabilities facilitate the cocreation of value (Karpen et al., 2012, 2015; Vargo \& Lusch, 2008). Moreover, SDL offers broad guidance in the form of "service as a transcending mental model” (Lusch \& Nambisan, 2015, p. 156).

This article adds to our understanding of strategy implementation an important dimension that has been largely unexplored to this point. It explains the prominent role of managing relationships (relational capital) and human capital in the effective implementation of strategy, thereby contributing to the fields of strategic management and SHRM.

In the following sections, we argue that such capabilities provide options for resource management, add to the firm's stock of HCR, and lead to more effective strategy implementation.

\footnotetext{
${ }^{1}$ As a point of clarification, we refer to SDL, SDO, a service view, or a service perspective in an analogous manner. We refer specifically to SDL, SDO, or service orientation in some instances to maintain fidelity with the literature under discussion.
} 
TABLE 1

Service-Dominant Logic in a Nutshell

\begin{tabular}{|c|c|}
\hline Selected key concepts & Description \\
\hline Resources & $\begin{array}{l}\text { A resource is anything that can be } \\
\text { drawn upon for support-either } \\
\text { tangible or intangible, internal or } \\
\text { external to the actor, operand or } \\
\text { operant. Resources are a function of } \\
\text { human appraisal. }\end{array}$ \\
\hline Resource integration & $\begin{array}{l}\text { From the integration of resources new } \\
\text { resources emerge. These can in most } \\
\text { cases be disassembled back into the } \\
\text { component resources, but sometimes } \\
\text { the integration results in emergence } \\
\text { of a resource that cannot be } \\
\text { disassembled. This is often the case } \\
\text { with integration of intangible } \\
\text { resources. }\end{array}$ \\
\hline Customer focus & $\begin{array}{l}\text { The question is not what to sell } \\
\text { customers but more deeply how to } \\
\text { help customers to get one or more jobs } \\
\text { done (i.e., accomplish a goal or } \\
\text { resolve a problem). }\end{array}$ \\
\hline $\begin{array}{l}\text { Service embedded in } \\
\text { goods }\end{array}$ & $\begin{array}{l}\text { Service is a transcending concept: } \\
\text { Service can be provided directly or } \\
\text { indirectly via a tangible good. Thus, } \\
\text { all firms are service firms, and all } \\
\text { economies are service economies. }\end{array}$ \\
\hline Value in use & $\begin{array}{l}\text { This does not ignore value in exchange } \\
\text { but focuses on value in use by the } \\
\text { beneficiary. It involves deep learning } \\
\text { about how the beneficiary (customer) } \\
\text { uses the service you provide. }\end{array}$ \\
\hline $\begin{array}{l}\text { Dialogic } \\
\quad \text { communication }\end{array}$ & $\begin{array}{l}\text { This is focused away from debate and } \\
\text { toward learning together. Build trust, } \\
\text { solidarity, and relationships through } \\
\text { learning together at all levels of the } \\
\text { organization. }\end{array}$ \\
\hline $\begin{array}{l}\text { Co-creation and } \\
\text { co-production }\end{array}$ & $\begin{array}{l}\text { Co-creation is not optional; we all } \\
\text { depend on others, co-evolve, and co- } \\
\text { create. Most of this is indirect through } \\
\text { a service ecosystem. However, } \\
\text { a subset of co-creation is co- } \\
\text { production, where the entity is } \\
\text { directly involved in helping produce } \\
\text { market offerings. How can suppliers } \\
\text { and customers and potentially other } \\
\text { stakeholders be co-producers of } \\
\text { mutual benefits? What jobs can we } \\
\text { hire the customer to do? What jobs } \\
\text { can suppliers hire the firm to do? }\end{array}$ \\
\hline
\end{tabular}

Sources: Based on Vargo and Lusch (2004) and Vargo and Lusch (2016).

\section{UNANSWERED QUESTIONS WE ADDRESS}

There are several research questions regarding strategy implementation and managing human capital to facilitate implementation that require attention. They focus on topics in three major areas: customer integration in implementation, interdisciplinary approach, and multiplex (multilevel and multiunit) analysis. We address each in turn.

\section{Customer Integration in Implementation}

Strategy researchers have called for the inclusion of a greater customer perspective in strategic management (Priem, 2007). Such views are consistent with the growth of customer co-creation and co-production (Prahalad \& Ramaswamy, 2004) and calls for more integrated and less myopic approaches to implementation (Payne \& Frow, 2006). For example, firms that are customers can be integrated in the implementation of strategies using information-sharing processes in interorganizational supply chains (Lamberti, 2013). In firms pursing customer-centric strategies, the customer may be highly integrated in the implementation of a product development strategy, allowing the customer and firm to co-create a product that meets the customer's needs; the product can also be sold to other customers having similar needs (Galbraith, 2002). In the SDL perspective, customers are not passive entities to which firms target their products and services but rather active participants working with employees, suppliers, and other partners (Lusch \& Nambisan, 2015). Our work addresses this need by integrating the SDL with SHRM research to explain ways in which human capital can be managed to implement the firm's strategy.

\section{Interdisciplinary Approach}

Despite the application of theories from several disciplines (including psychology, economics, and finance) to strategy questions, the theoretical frameworks used to explain differences in strategies adopted across firms are unexpectedly parochial (reliance on monopoly barriers, resource scarcity, and Schumpeterian innovation). Accordingly, broader paradigms are needed to provide improved concept integration (Powell, Lovallo, \& Fox, 2011). Although the work on strategy implementation is less substantial, it uses highly traditional theoretical frameworks; thus, the same criticisms apply to the body of knowledge on strategy implementation. Improved paradigms, for example, should draw on disciplines such as organizational psychology to build commitment and effort needed for implementation.

Because implementation occurs within a context of imperfect control where discretionary behaviors 
are critical, more robust theoretical explanations will likely result from the incorporation of motivation theory. For example, reward theory could be used to highlight the power of visible recognition for successful implementation or to encourage and reinforce actions taken to redeploy marketing resources and activities to different market segments (Noble, 1999; Smith, 2009). Our application of SDL provides an interdisciplinary perspective for strategy implementation that draws on the marketing and service management disciplines.

\section{Multiplex (Multilevel and Multiunit) Analysis}

Failures in implementation have often occurred because of a myopic attention to only one level of managerial analysis (Gratton \& Truss, 2003) or one focus within the organization. We employ a multilevel analysis by addressing application of SDL at the individual level, hierarchical levels within the firm (senior management, middle management, operating management, and employees), the firm level, and interfirm levels. These levels of analysis are interwoven throughout discussions as we progress from individuals to hierarchies or networks of individuals in the firm to firms and to interfirm relationships (including customers and suppliers). We devote substantial attention to the implications of SDL at the individual level, as Mantere (2008, p. 312) reminded us that "[o]rganizations do not create, implement or renew strategies. People do."

A major portion of our discussion applies SDL to middle management, where responsibility for implementation is critical and where important challenges are often encountered (Floyd \& Woolridge, 1992; Guth \& Macmillan, 1986; Huy, 2011; Mantere, 2008; Woolridge \& Floyd, 1990). In this vein, we explore how SDL-based insights enable top managers to work more effectively with middle management on implementation. Unfortunately, top-level executives have often failed to attend to socio-emotional issues (e.g., loss of status, anger) that can derail implementation, such as when strategies are formulated through top-down approaches (Huy, 2011). Arguably, lower-level managers and operating employees have similar concerns in these instances.

We then apply SDL insights at the level of the firm (systems) and to interactions beyond the boundaries of the firm (interfirm interactions and ecosystems thinking). This is also critical because implementation must be an organization-wide process involving all units, with significant coordination and integration of activities. It also requires integrating external partners, including customers and suppliers, into the process. Relational capital facilitates implementation with external partners as well as at individual and interfirm levels. We integrate relational capital into several aspects of implementation that are discussed later.

\section{STRATEGY IMPLEMENTATION}

A primary research question that underlies much strategic management research is this: Why do some firms perform better than others? A significant amount of the research has tried to address this question by identifying the strategy that will produce a competitive advantage and create value for the owners. In the past few decades this question has been examined in many different contexts, but it cannot be fully answered by focusing only on the formulation of the "right" strategy. Even if a strategy is optimal for the firm, it also must be implemented effectively to create value. Flawed implementation is often the reason for failures in strategy (Hickson, Miller, \& Wilson, 2003; Nutt, 1999; Raes, Heijltjes, Glunk, \& Roe, 2011). Moreover, some argue that effective implementation of strategy is more challenging than designing a good strategy (Hrebiniak, 2005). Although strategies are often difficult to implement, recent research suggests that effective implementation of at least reasonable strategies (even though imperfect) still provides benefits (Lee \& Puranam, 2016).

Much of the research on strategy implementation has focused on matching the organizational structure to the strategy chosen, on strategic leadership, and to a degree on corporate governance. However, a large portion of the governance research and research on strategic leadership (e.g., CEO and top management team) has examined the role of governance and top management in selecting a strategy that provides a competitive advantage to the firm (see Dalton, Hitt, Certo, \& Dalton, 2007; Finkelstein, Hambrick, \& Cannella, 2009). A great deal of the implementation research has focused on the type of structure needed to implement different types/levels of diversification strategy. For example, Hill, Hitt, and Hoskisson (1992) argued that each type of diversification strategy requires distinctly different types of internal organizational arrangements to realize its potential returns. Alignment between the structure and the strategy may be necessary, but it is an insufficient condition alone to implement a firm's strategy. Long ago, Schendel and Hofer (1979) suggested that to 
implement a strategy, executives must develop goals, monitor internal operations, and build effective external relationships (e.g., with customers and suppliers).

Thus, strategy implementation begins with the top management team because the team is responsible for its development. Barrick, Thurgood, Smith, and Courtright (2015) showed that the top management team initiates strategy implementation processes, first creating goals and subgoals and then taking actions necessary to ensure that those goals are achieved. A critical set of these actions involves the management of the firm's resources (e.g., allocating resources to various tasks that must be completed to implement the strategy). Sirmon, Hitt, and Ireland (2007) suggested that resources must be acquired, accumulated (developed), and sometimes even divested in the active management of the firm's resource portfolio. Further, top managers need to bundle (allocate/assign) resources to create the capabilities needed to accomplish the tasks. Then middle- and lower-level managers must leverage those resources/capabilities to implement the selected strategy (Sakhartov \& Folta, 2015; Sirmon \& Hitt, 2009).

The implementation process requires not only managers but the whole workforce (at multiple levels) to perform the tasks assigned and complete them effectively. Managers must provide incentives for the employees to perform well (e.g., rewards) and work with them to ensure that they cooperate and collaborate, as most tasks require collective effort (Hrebiniak, 2005). And collaboration may need special emphasis, as there is evidence that it may not be adequately rewarded (Sull, Homkes, \& Sull, 2015). Human capital is critical to the successful implementation of strategy. Yet Hrebiniak (2005) argued that middle- and lower-level managers are commonly trained to plan but are not shown how to effectively execute. Thus, they can become overly focused on responding to and trying to resolve problems but lose their focus on the actions necessary to implement the firm's strategy. Additionally, Sull et al. (2015) argued that most managers find the people in their units willing to help implement the firm's strategy but encounter problems in gaining the support and coordination needed from other internal units and external partners (e.g., suppliers).

Often, building relationships with the firm's stakeholders is critical for implementing a firm's strategy. Perhaps the most important stakeholders are the customers. Indeed, the firm must provide superior value to the customers relative to other competitors to achieve a competitive advantage. To do so, the firm must build and maintain a quality relationship with its customers, which as noted earlier requires more than a passive role. The firm must also build and maintain good relationships with other stakeholders such as suppliers because they are a source of external resources often needed to develop the capabilities to implement the strategy effectively. Thus, firms must build relational capital to facilitate strategy implementation. According to Uzzi (1997), relational embeddedness exists when there is trust, regular information exchange, and joint problem solving between the parties. Such embeddedness leads to the development of relational capital, which involves joint benefits derived from a relationship that is very important to the parties involved. And relational capital with customers and other important stakeholders helps firms implement their strategies (Hitt, Bierman, Uhlenbruck, \& Shimizu, 2006). Implementation also often requires the sharing of intellectual property (IP), which can be protected by relationships (Baldwin \& Henkel, 2015), especially when statesanctioned IP rights are ineffective or too costly to enforce.

When firms manage their human capital in ways described herein and build quality relationships with stakeholders, they can more effectively implement strategy. As discussed later, SDL is inherently relational, which facilitates relationship building. These relationships become part of the firm's relational capital (Adler \& Kwon, 2002; Leana \& Van Buren, 1999), which facilitates implementation. Relational capital helps the firm access new resources, especially human capital, and better use of existing capabilities based on the firm's human capital. Although Becker and Huselid (2006) argued that human capital plays a critical role in the strategyimplementation process, few scholars have examined the precise role played or how it must be managed to execute the strategy effectively.

\section{HUMAN CAPITAL RESOURCES AND IMPLEMENTATION}

\section{Resources and Capabilities}

Barney (1991) argued that resources that are valuable, rare, inimitable (or difficult to imitate), and nonsubstitutable by other resources (sometimes referred to as VRIN resources) produce a competitive advantage for firms. Barney's work on the resourcebased view (RBV) continues to be influential today, 
but it also has received noteworthy criticism. Perhaps the most prominent critique was provided by Priem and Butler (2001). Among their criticisms is that merely possessing VRIN resources is insufficient to produce a competitive advantage or to create value. Those resources must be managed in ways that create value for (and sometimes with) customers and gain an advantage over competitors. Creating this value requires that the resources and capabilities derived from resources are deployed to implement the firm's strategy.

Capabilities are deployed through the human capital in the firm. Human capital is the knowledge, skills, and capabilities of individuals, which are often based on a person's education and experience (Hitt \& Ireland, 2002). Drawing on their human capital, managers make decisions and take actions and employees perform prescribed tasks to implement the firm's strategies. In support of this conclusion, Hitt, Bierman, Shimizu, and Kochhar (2001) found that the level of human capital moderates the relationship between a firm's strategy and performance. Thus, human capital is used to implement the firm's strategy, and the firm's capabilities determine how well the strategy is implemented-thus affecting the firm's performance. In support of this conclusion, Hitt et al. (2006) found that firms use their human capital to implement an international strategy; firms with higher levels of human capital are able to implement internationalization more successfully (i.e., higher performance).

Given the importance of human capital for the implementation of strategy, firms must manage (leverage) their human resources in effective ways. For example, Vomberg, Homburg, and Bornemann (2015) found that human resource practices that enhance skills, motivation, and opportunities for the workforce contribute to greater human capital, which in turn has a positive effect on firm value. Thus, firms need to attract (recruit), develop, deploy in effective ways, and retain high-quality human capital to implement the firm's strategies in ways that create superior value for customers and thus build a competitive advantage.

\section{Resource Management and Human Capital}

Research suggests that the effectiveness of the firm's management of its resources can explain differences in the performance of the firm relative to others that have similar resources. Through resource management, the firm bundles and deploys these resources in complex combinations that create new capabilities for value creation. Human capital is a critical portion of the resources that are packaged and deployed to create such capabilities (Barrick et al., 2015; Ployhart, Nyberg, Reilly, \& Maltarich, 2014; Sirmon et al., 2007).

The firm's human resource practices and systems are important for its creation of capabilities needed for competitive advantage. For example, the practices used to manage the firm's HCR, such as those involved with skill development, performance management, and deployment, influence its abilities to bundle and combine HCR to create capabilities (Ketchen, Crook, Todd, Combs, \& Woehr, 2017; Sirmon, Gove, \& Hitt, 2008). Moreover, human resource systems help develop the firm's relational capital, which can be used to promote coordination among internal units and with external partners (Youndt \& Snell, 2004). The conventional wisdom is that the firm's architecture of HR systems and practices (which help develop such capabilities) should be vertically aligned or contingent on the firm's strategies, although the empirical evidence could be more persuasive (Becker \& Huselid, 2006; Colbert, 2004; Datta, Guthrie, \& Wright, 2005; Delery \& Doty, 1996; Lepak \& Shaw, 2008).

Some scholars have responded to the call (noted earlier) by Becker and Huselid (2006) to investigate the processes and mechanisms that mediate the relationship between HR systems or practices and organizational outcomes (Beltran-Martin, Roca-Puig, Escrig-Tena, \& Bou-Llusar, 2008; Chuang \& Liao, 2010; Jiang, Lepak, Hu, \& Baer, 2012; Liao, Toya, Lepak, \& Hong, 2009). In these studies, customer and service orientations were found to mediate the relationship between HR systems and organizational outcomes (Chuang \& Liao, 2010), while human capital was found to mediate the relationship between HR systems and service (Liao et al., 2009). Nonetheless, the SHRM literature has mostly focused on the implementation of HR systems rather than important resource management questions such as bundling and deployment of HCR. Customers and service were typically treated as outcome variables in these studies (e.g., Beltran-Martin et al., 2008; Gibson, Porath, Benson, \& Lawler, 2007; Liao et al., 2009). However, none of these studies specifically examined the relationship between human resource architectures and the implementation of the firm's strategy, which was the void noted by Becker and Huselid (2006). Thus, understanding the influence of differentiated HR architectures on strategy implementation (such as innovation) provides an opportunity for more normative and contextually specific 
guidance on how to manage HCR (Becker \& Huselid, 2006; Colbert, 2004).

Human resource practices and systems are only part of the picture. Greater HCR and relational capital are also developed with learning and transfer of tacit knowledge from frequent (reciprocal) interactions between members of the firm's workforce and external stakeholders (e.g., customers and suppliers) (Adler \& Kwon, 2002; Ployhart \& Moliterno, 2011). Indeed, a combination of the firm's human resource practices and the effective management of its capabilities coupled with workforce engagement is needed for implementation (Barrick et al., 2015). And when the workforce is engaged, there is better coordination and collaboration, which helps to overcome one of the primary foils of the strategyimplementation process identified by Sull et al. (2015).

However, there are challenges in managing HCR for effective implementation. For example, the bundling and deployment of human resources may be constrained by contextual influences in the environment, such as the requirements for trust and positive relationships with customers. And there are often practical challenges involved in deploying some of the firm's best employees (e.g., relocation concerns) (Sirmon et al., 2007, 2008; Sirmon \& Hitt, 2003). A key to the integration of HCR in the development of organizational capabilities is the presence of shared mental models (such as SDO) that provide guidance to employees regarding the behaviors that are expected and rewarded. Such shared mental models (or shared perceptions) can facilitate coordination and accomplishment of required tasks (Bowen \& Ostroff, 2004; Ketchen et al., 2017). The guidance and coordination resulting from shared mental models increases the likelihood of success in bundling and deploying the firm's HCR to create the capabilities needed for implementing strategies.

Given this background, in the following sections we argue that incorporating a service perspective provides a more fine-grained view of resource management that offers insights for HCR utilization in strategy implementation.

\section{SERVICE AND HUMAN CAPITAL RESOURCES}

\section{Service-Oriented HCR}

A service perspective extends our understanding of the management of human capital within organizations. This perspective views all employees as providing service to one another or other stakeholders of the organization (Lusch \& Vargo, 2014). This view includes the potential for employees to act as collaborators in helping the organization provide a compelling value proposition for (and with) customers and other stakeholders (Lusch et al., 2007). Importantly, there is empirical support for the positive contributions of a service perspective to organizational performance. For example, employee service orientation increases effectiveness at the unit level over time (Ployhart, Weekley, \& Ramsey, 2009). SDO, which as noted earlier is grounded in SDL principles, has been found to be positively related to the firm's market and financial performance as well as to customers' perceptions of the value of an exchange and affective commitment to and trust in an exchange partner (Karpen et al., 2015). Other evidence shows that a service orientation produces outcomes consistent with customer value creation, such as greater customer satisfaction and loyalty and enduring customer relationships (Teng \& Barrows, 2009), which contributes to the firm's ability to create value for shareholders (Sirmon et al., 2007). Based on such evidence, scholars have argued that service orientation provides an organizational capability and is a form of human capital (Aryee, Walumbwa, Seidu, \& Otaye, 2016).

Moreover, a service perspective helps to create an ever-changing and dynamic mix of human capital (and a deeper pool) by facilitating the dissemination of unique proprietary information (such as insights on customer needs) (Aryee et al., 2016). Customer insights and relationship knowledge (including internal customers) are embedded in the firm's HCR and are largely tacit (Hitt et al., 2001). Much of the information needed for implementation is disseminated by relational rather than transactional exchange. And dissemination is facilitated by advancements in organizational continuity, collaboration, trust, and engagement, all of which are promoted by enduring service-oriented relationships. Firms use the relational capital of their HCR to create the trust needed for collective action (Leana \& Van Buren, 1999) and thus promote coordination and collaboration. Moreover, as noted earlier, collective action is critical for implementation (Hrebiniak, 2005). As combinations of the firm's HCR are bundled, the firm develops unique and complex relational capital, which helps build relationships among employees (internal customers), customers, and external partners (such as suppliers and other important 
stakeholders). As such, a service perspective leverages the unique abilities of the firm's HCR to implement its strategies. A summary of the contributions of SDL to the management of HCR for strategy implementation is provided in Table 2.

\section{Attending to Socio-Emotional Issues}

As noted earlier, socio-emotional issues have provided challenges to implementation. For example, middle managers are likely to resent the actions of top management when their input in formulation of the strategy is not solicited or is not used when solicited (Woolridge \& Floyd, 1990). Contagious negative emotions may also be triggered by mistreatment of middle managers as a group with a resultant loss of receptivity (Huy, 2011). Such disregard for involvement reflects a lack of respect by top managers (as noted earlier in Hrebiniak, 2006), and also reflects a lack of understanding of mutual dependence and exchange, which are hallmarks of SDL. This relationship has been succinctly expressed as follows:

The strategist needs the implementer and vice versa. You cannot build strategy on the top floor where the elevators are locked.... You have to have the experience from the customer interface. And this is what we [middle managers] provide the people on the top floor.... The atmosphere of respect appears to be reached through an exchange where the top management shows respect for the competencies of middle managers and their teams, and they respond by showing respect for the strategy work of top management. (Mantere, 2008, p. 306)

Top managers need to respect the implementation work of middle managers and demonstrate that they do not view this work as mechanical or easily replaceable (Mantere, 2008). Support for this normative prescription is provided by survey research on the implementation of customer relationship management (CRM) strategies, which revealed that the lack of "soft skills" can pose a far greater challenge than technical complexity (Bohling et al., 2006).

From an SDL perspective, top managers are better guided by a reciprocal view (with multilevel application). In this view, top and middle managers exchange service for the benefit of one another, the organization, customers, suppliers, and other stakeholders who may be involved in collaboratively co-creating and implementing strategy (Lusch et al., 2007). Thus, collaborative competence becomes a means for the firm to acquire knowledge, which must be constantly updated to sustain a competitive advantage (Lusch et al., 2007). Moreover, while the need for respect from top managers has been emphasized, the need for respect is reciprocal, as

TABLE 2

Service Perspective for Human Capital Resources in Strategy Implementation

Elements of service-dominant logic and service-dominant orientation

- Establishing the primacy of transcending service relationships

- Focusing on customers and other stakeholders

- Exchanging service rather than transactions focused on goods

- Fostering enduring relationships

- Emphasizing mutual respect

- Emphasizing candid dialogue rather than propaganda

- Engaging in symmetrical information exchange

- Relying on mutual trust created by relationships

- Collaborating and doing things together

- Focusing on continuity

- Evolving with interdependency

- Emphasizing reciprocity
Management of human capital resources

- Applying guidance from SDL and SDO

- Selecting and developing HCR with SDO capabilities

- Minimizing status differentials

- Developing capabilities for knowledge transfer

- Developing capabilities for relational complexity

- Bundling complementary HCR with insights from SDL and SDO

- Developing HCR that will promote continuity

- Developing systems for rewarding cooperation and reciprocity

- Selecting and developing HCR with boundary-spanning capabilities

- Deploying resources with consideration of the context (e.g., right people in the right place)
Implications for strategy implementation

- Sharing high-quality knowledge

- Facilitating feedback for learning and adaptation

- Collaborating and co-creating with customers and other stakeholders

- Treating customers as active rather than passive participants

- Incorporating systems thinking and consideration of interdependencies

- Leveraging boundary-spanning SDO capabilities

- Using notions of service ecosystems for coordination of resources

- Aligning interests of stakeholders 
middle managers need to respect the work of those creating the strategies (Mantere, 2008). In addition, the respect should exist throughout the organization and in its relationships with customers, suppliers, and other stakeholders.

Proposition 1: SDO fosters respect among those involved in strategy implementation.

\section{Greater Emphasis on Dialogue}

Managers (often at middle and lower levels) who are charged with implementing strategy sometimes engage in "issue selling" and "moves." Such actions are intended to upwardly focus the attention of top managers on issues in implementation, help shape the strategy, and transform implementation into a more emergent and inclusive process (Dutton, Ashford, O’Neill, Hayes, \& Wierba, 1997; Narayanan, Zane, \& Kemmerer, 2011). These processes represent countervailing forces to top-down approaches and may draw on the guidance of a "complex selling recipe" bundling the appeal with data and a solution (Dutton et al., 1997; Dutton, Ashford, O’Neill, \& Lawrence, 2001, p. 729). It may be argued that the emphasis on selling (i.e., need to be persuasive) can reflect a lack of genuine dialogue in some instances. For example, the literature has provided normative guidance suggesting that strategies should be "sold" to those having responsibilities for implementing them as well as other stakeholders affected by them (Pinto \& Prescott, 1990).

The strategic management literature has noted the need for more ongoing strategic conversations (or dialogue) between top management and lower-level managers to improve the responsiveness (via enhanced organizational sense-making) of those involved in implementation (Love, Priem, \& Lumpkin, 2002). Similarly, SDL emphasizes an architecture of participation in actor-to-actor networks to coordinate service exchange (Lusch \& Nambisan, 2015). However, there are complexities that should be considered. For example, explicit communication about strategy may be needed in more centralized firms where managers have little discretion in the implementation process (Love et al., 2002). Thus, the level of explicitness in strategy articulation should be matched with the level of managerial discretion. This avoids the pretense of seeking the input of mid-level managers who implement strategy when they have little or no discretion. Taking this approach is consistent with SDL's emphasis on open and honest communication and admonition against the use of propaganda. In addition, SDL suggests the importance of feedback from managers charged with implementation as a means of continuous learning and refining strategy as needed. Using the service orientation of SDL increases the likelihood that those charged with implementation will be consonant with top managers because of receptiveness to candid upward feedback that is given appropriate weighting in further decisions.

Proposition 2: SDO fosters candid dialogue throughout the organization during strategy implementation.

\section{Fostering Trust and Commitment}

The development and maintenance of a service perspective (or orientation) as a form of HCR is an important consideration because the stock of HCR and the capabilities it provides for implementation tends to ebb and flow over time (Ployhart et al., 2009). Moreover, the capabilities provided by a service orientation within the firm's HCR are likely to require time to develop. Service exchanges lead to bonding and the development of personal connections over time (Gremler \& Gwinner, 2000). The development of such connections is important because bonding between managers and employees helps build commitment and trust that foster motivation needed for the implementation of goals (Sullivan, 1988). Furthermore, the trust that is critical for a service perspective to emerge takes time to develop and maintain (Karpen et al., 2015). Over time, the application of skills and competencies provides benefits to others (Vargo \& Lusch, 2004), and with acts of benevolence there is an increase in trust (Schoorman, Mayer, \& Davis, 2007). Moreover, greater trust is likely when exchanges are reciprocal (involving acts such as help and advice) (Rao, Pearce, \& Xin, 2005). With time the trust that develops can then offset some of the risk involved in implementation. For example, with greater trust a provider can propose a variation in service entailing more risk that better fits the customer's needs (Webber, Payne, \& Taylor, 2012).

Proposition 3: SDO fosters the development of trust and commitment among all parties involved in strategy implementation.

\section{FOSTERING ENDURING RELATIONSHIPS}

Over the last several decades in the field of marketing there has been a rising focus on relationship 
marketing, which developed along with the field of service(s) marketing (Rust \& Chung, 2006). Relationship marketing focuses on customers and other parties vital to the firm's success. In fact, employees are a critical part of relationship marketing because they are viewed as internal customers. Importantly, the link between trust and commitment is a major factor in relational exchanges in relationship marketing (Morgan \& Hunt, 1994). Similarly, a service perspective emphasizes enduring relationships (in contrast with transactional views), lower status differentials, more collaboration, and more honesty in dealings with customers and other stakeholders (such as suppliers) (Greer, Lusch, \& Vargo, 2016; Guitián, 2015). This perspective also has similar implications for how people deal with each other within organizations, particularly with respect to the senior leadership team and other employees (across levels and disciplines). With such a perspective, there is a greater inclination for open and honest conversation and dialogue across the organizational hierarchy and less opportunistic behavior (Morgan \& Hunt, 1994). Listening is valued because communication is not intended to be in only one direction (Lusch, Vargo, \& Malter, 2006). With communication reflecting consideration of others (which is reflective of a service perspective), there is likely to be greater bonding between managers and employees (Sullivan, 1988).

Implementation is also more effective when members of the top management team and middle managers trust each other and are able to influence and learn from each other (Raes et al., 2011). Thus, trust facilitates coordination throughout the organization. Conflicts, which are inevitable in implementation, are more easily resolved with durable solutions when members of these groups understand one another's needs and interests. Such understanding is reflective of a service perspective (Brickson, 2007). With a focus on the identification and satisfaction of interests, the parties are better able to resolve conflicts through integrative approaches, which can add value to the strategy implementation (Raes et al., 2011). Moreover, with greater trust and stronger relationships, feedback between members of the firm and customers is more likely to be honest, thereby helping to improve the service (where needed) (Lusch et al., 2006). Authentic communication should facilitate more corrections and incremental adjustments in strategy and the implementation process. In turn, these relationship attributes and outcomes (such as directed toward mutual need satisfaction) often develop more enduring relationships.
Unfortunately, poor vertical communication frequently creates a major barrier to effective strategy implementation. Such barriers are reflected in the lack of honest upward feedback from employees, an absence of open dialogue about the difficulties of implementation, and the reluctance of employees to disagree with the views of the top executives (Beer \& Eisenstat, 2000). Without a willingness to hear the unvarnished truth from employees, top executives are unlikely to learn what they need to know for guiding changes to the implementation process or refinement of the strategy. While the CEO and top management team are expected to establish the direction and the goals, they also need to learn from employees when they experience problems and challenges in the strategy-implementation process. Moreover, without such learning (and lacking a multiplex approach), these top executives will lack the knowledge to guide the further development and implementation skills of middle- and lower-level managers (Beer \& Eisenstat, 2000).

Proposition 4: SDO fosters the development of enduring relationships among all parties involved in strategy implementation.

\section{CO-CREATING IMPLEMENTATION}

Based on historical precedents dating back to the industrial revolution, some organizations operate in a very hierarchical manner. In these organizations, top management formulates the strategy and then directs middle- and lower-level managers to implement it. This approach is the antithesis of a service perspective and SDL. The arguments and propositions we have presented to this point suggest that such an approach is likely to be ineffective in both developing and implementing a strategy. A service perspective (and SDL in particular) places emphasis on working together and focusing on co-creation (such as with customers and other stakeholders).

Co-creation is facilitated with dialogic communication, and dialogue is a critical element of SDL (Ballantyne \& Varey, 2006). Dialogue facilitates the process of learning together (both/all parties benefit) and is quite different than directive communication (telling others what to do) and debate (disputing who is right or wrong), both of which typically involve a win-lose strategy. When directed from the top down, strategy implementation is often accompanied by persuasive informational messages that focus on trying to control the outcomes without the benefit and knowledge of the middle- and lower-level 
managers and employees involved in execution (implementation). With a dialogic approach, the focus is on "finding a voice in co-determination" (Ballantyne \& Varey, 2006, p. 229) and co-creating through learning together. As organizations evolve to a network and ecosystems approach (which we explore later), emphasizing co-creation is an effective way to coordinate. Co-creating involves behaviors such as listening to others (internal and external stakeholders), trying to understand their needs, respecting their interests, and using their talents in a collaborative manner. Such an approach often produces an organizational culture that fosters mutually beneficial value co-creation.

With its relational focus, the service perspective also inculcates sensitivity to the nature of interactions with other actors at the boundaries of the organization (Schneider \& Bowen, 1995), which are increasingly important for implementation. For example, the evolving service-oriented perspective emphasizes the importance and value of providing service in a continuous and interactive manner. This mode of interaction emphasizes exchanges of a relational rather than a transactional nature with concern for future relationships and the welfare of others (Lusch et al., 2006; Lusch, Vargo, \& Tanniru, 2010).

Proposition 5: SDO fosters co-creation (collaboration, working together) among all parties involved in strategy implementation (internal and external to the organization).

\section{IMPLEMENTATION IN CONTEXTS OF INTERDEPENDENCY}

The interdependencies among different actors are reflected in the strategic management literature (e.g., Kor \& Leblebici, 2005; Sirmon \& Hitt, 2009), the HR literature (Mossholder, Richardson, \& Settoon, 2011; Trevor, Reilly, \& Gerhart, 2012), and the services management literature (Bowen \& Schneider, 1988; Larsson \& Bowen, 1989; Mayer, Ehrhart, \& Schneider, 2009). Nonetheless, these literatures have not been integrated to reflect the extent to which implementation creates interdependencies among individuals and units throughout the organization and beyond.

S-D logic takes an ecosystem perspective (explained in detail later) that inherently involves interdependencies among people and entities. The ecosystem context can be thought of as the connections, exchanges, and other flows between actors (firm, employees, customers, suppliers, government, etc.) that create a web of interdependencies (Akaka, Vargo, \& Lusch, 2013). These complex contexts are socially dynamic. For instance, employees (diverse resources) interact with other employees, and through interactions learn and acquire knowledge (Akaka et al., 2013). The employees or other social actors are influenced by social norms and other informal institutions (e.g., culture) (Akaka et al., 2013; Vargo \& Lusch, 2016).

As we have argued, knowledgeable individuals with specialized skills are at the core of strategy implementation. With increases in specialization there is greater interdependency, which evolves into highly complex constellations of interdependencies on a broader scale. In such contexts of interdependency, the absence of cooperative relationships brings a greater likelihood of failure. Findings from micro-level research indicate that in struggles for control where there is high interdependence, both parties fail (employees and customers) if they cannot achieve a resolution (Rafaeli, 1989). The SDO emphasis on continuing service exchange among a network of actors contributes to systems thinking, which is needed for implementation in contexts of complex and socially dynamic interdependencies. This stands in contrast to the context of dyadic transactional exchanges of goods for money.

The nature of HR systems is particularly relevant to the management of HCR for firms' strategy implementation in such contexts. This is because these systems influence the nature of relationships and encourage employee behaviors such as helping, cooperation, and affiliative behaviors directed toward other individuals (Mossholder et al., 2011). These collaborative behaviors are especially important when there are multiple institutional logics (understandings/rules of the game) in operation, which is common in complex organizations with multiple external stakeholders (Ramus, Vaccaro, \& Brusoni, in press; Vargo \& Lusch, 2016). Unfortunately, cooperation and collaboration have often been under-rewarded by such systems, and they need to be aligned with the behavioral requirements for strategy implementation (Sull et al., 2015). We need research on how reward and compensation systems can be better aligned to encourage appropriate SDO-focused behaviors in the context of multiple institutional logics (Karpen et al., 2015).

Other important aspects of interdependencies influence implementation. For example, the likelihood of successful implementation is greater when the mutual dependencies in formulation and implementation are acknowledged. Implementation and 
strategy formulation should be considered simultaneously, and those most heavily involved with implementation should also have input into the formulation process. Learning and feedback are also critical for implementation because a firm's strategy is often refined over time with knowledge gained during implementation processes. In turn, these processes facilitate the firm's adaptation to its competitive context and other important external stakeholders (Argyris, 1989; Hrebiniak, 2006; Nutt, 1999). The resolution of differences in interests, which should become apparent with learning and feedback, is facilitated by SDO. Because SDL aims to improve the value of the firm by increasing the value of the entire set of its stakeholder relationships (Lusch \& Webster, 2011), there is incentive for the alignment of interests (Abela \& Murphy, 2008). And such incentives for alignment of interests likely facilitate the implementation process. This is evident from Hrebiniak's (2006) process view of strategy implementation, which suggests that implementation is not an individual decision or action but a series of connected decisions and actions over time, in which different interests can be aligned.

The normative guidance provided by a service perspective is especially valuable in the context of significant interdependencies. This approach is in contrast with the more sterile focus of market mechanisms, as proposed in transaction cost economics (TCE) theory (Coase, 1937; Ghoshal \& Moran, 1996; Rindfleisch \& Heide, 1997; Williamson, 2010). With TCE there is no allowance for cooperative intent (White \& Lui, 2005), which is embedded in a service perspective because of its emphasis on the value of relationships (Abela \& Murphy, 2008). As we have discussed, with a service perspective the decision for exchange is not based merely on selfinterest. Instead, the decision to exchange relies on affective and emotional bonds and shared values (Mossholder et al., 2011). Indeed, researchers have noted the problem of relying on market-based theories for managerial guidance on decisions such as outsourcing. For example, TCE fails to recognize the viability of relying on trust in relationships with other firms to reduce transaction costs as an alternative to bringing the activity inside the firm (Crook, Combs, Ketchen, \& Aguinis, 2013). TCE also offers only limited insights into the firm's capabilities for decisions on outsourcing because it does not capture the individual and social knowledge that comprises these capabilities (Kogut \& Zander, 1992; Xiao \& Tsui, 2007). Thus, more emphasis should be placed on relational governance versus merely market or hierarchical governance, as is the focus of TCE (Zajac \& Olson, 1993). In this vein Ghosh and John (1999) introduced the concept of governance value analysis to extend TCE to include relational exchange versus merely hierarchy (firm) and market exchange mechanisms.

Proposition 6: SDO fosters positive interdependent relationships that facilitate strategy implementation.

\section{IMPLEMENTATION ACROSS ORGANIZATIONAL BOUNDARIES}

Increasingly, strategy must be implemented in a context of interdependency where there is need for coordination across organizational boundaries. Relationships are highly important for value creation in extended organizations, which include external stakeholders such as firms in the supply chain and alliance partners (Dyer, 2000; Post, Preston, \& Sachs, 2002; Webster \& Lusch, 2013). Moreover, greater experience with the same partners generally promotes the development of trust and relational capabilities, which help them to jointly create more value (Gulati, Lavie, \& Singh, 2009). In turn, relationships and trust-along with collaborative skills, collective identity, and webs of interpersonal connectionsfacilitate the management of the extended organization and enable the firm to build relational capital and thereby achieve a collaborative advantage (Dyer, 2000; Kanter, 1994). And as we have noted, cooperation and collaboration in contexts of interdependency are critical for strategy implementation. Moreover, a relationship mindset, which flows from an SDO approach to managing HCR, can help guide strategic decisions and their implementation by emphasizing the integration and balancing of stakeholder interests (Chen \& Miller, 2011; Lusch \& Webster 2011).

We argue that SDO provides valuable guidance for leveraging boundary-spanning capabilities that can be used in implementing strategy across organizational boundaries. The management of networks of individuals, units, and firms in these interdependent constellations entails network coordination and knowledge management (Möller \& Svahn, 2006). A service perspective that emphasizes building and maintaining relationships can facilitate implementation of operational strategies necessary in boundary spanning, such as the sharing of technologies. For example, researchers studying collaborative implementation of supply chain technologies 
have found better logistics and financial performance when there are higher-quality relationships between retailers and their suppliers (Richey, Tokman, \& Dalela, 2010).

While scholars have called for greater integration and the replacement of rigid boundaries between organizations, customers, and other stakeholders with highly permeable boundaries (Schneider, White, \& Paul, 1998), there are significant challenges involved in permeating rigid organizational boundaries that limit the effectiveness of strategyimplementation activities. For example, differences in goals and HR policies between collaborating organizations can impede the quality of service delivered (Marchington, Rubery, \& Grimshaw, 2011). Organizational structures with a parochial focus and a lack of managerial commitment to a broad talentdevelopment strategy can inhibit collaboration and knowledge sharing and limit the development of HCR capabilities needed for implementation (Schuler, Jackson, \& Tarique, 2011).

Even at lower levels in the organization, there is a need for managers who can lead implementation initiatives that cross functions and organizational boundaries (Beer \& Eisenstat, 2000). In line with these developments, service research has highlighted the need for T-shaped individuals who have both collaborative skills (breadth) to work with people across different disciplines and substantial expertise (depth) in their areas of competence (Bitner, Ostrom, \& Morgan, 2008; Bowen, 2016). Such skills are particularly relevant for service innovations, and unsurprisingly one of the leaders in innovation, IBM, has emphasized its need for Tshaped people (Bitner et al., 2008). The HR literature has also identified the need to develop T-shaped people who have the brokering and integration skills needed for implementation of innovation strategies (often requiring collaboration across disciplines and organizational boundaries) (Greer \& Stevens, 2015; Hunter, Cushenberry, \& Friedrich, 2012; Kang, Morris, \& Snell, 2007; Koruna, 2004). Because the supply of service-oriented individuals who have these skills is limited, firms have to align their staffing and development systems to ensure sufficient HCR for deployment to implementation assignments that cross boundaries.

Approaches for promoting cooperation across organizational boundaries (both internal and external) are needed to identify and exploit value-creation opportunities (Gratton, 2011). These may require specialized selection, training, and management for the development of employees who work on such boundaries-that is, the boundary spanners (Schneider \& Bowen, 1995). There is also a need to avoid potential threats to implementation from turnover. One practical suggestion is redundancy planning, which provides a practical way to reduce the risk of the departure of employees who span the boundaries between provider and stakeholder firms. Another practical suggestion is to train employees as potential replacements for boundary spanners (Lovett, Harrison, \& Virick, 1997).

\section{Proposition 7: SDO fosters boundary-spanning competencies that facilitate strategy implemen- tation in the extended organization.}

\section{ECOSYSTEMS THINKING}

There has been increased discussion of using ecosystems as a metaphor for understanding business and the development of strategy. For instance, Iansiti and Levien (2004) applied ecosystems thinking to strategy development, and Adner (2006) argued for matching a firm's innovation strategy to its innovation ecosystem. Teece (2007) has also emphasized the value of an ecosystems view in strategy for refining the dynamic capabilities framework. More recently empirical work by Kapoor and Lee (2013) called attention to the strategic interdependence of firms in business ecosystems and the implications for investments in technology. Additionally, Adner and Kapoor (2016) linked ecosystems thinking to issues in innovation strategy such as competing technologies, and interdisciplinary work spanning management and evolutionary biology has focused on organizations as ecosystems (Mars, Bronstein, \& Lusch, 2012). There has also been a recent examination of the biology of corporate survival (Reeves, Levin, \& Ueda, 2016).

As suggested by Mars et al. (2012), an ecosystems perspective can be used to understand business and service systems. Ecosystems are relatively selfcontained, which means they have some boundaries, although they are fuzzy. For instance, Apple's digital ecosystems have approximate boundaries. These ecosystems consist of an actor-to-actor network that involves interfaces, exchanges, competition, and cooperation. They are also self-adjusting by means of decentralized actors who directly experience a world filled with risk and uncertainty and thus sense and respond through adaptation. This process alone creates disturbances for other actors (species or firms) that require adaptation. Thus, ecosystems are dynamic. SDL within the concept of 
a service ecosystem (Vargo \& Lusch, 2011, 2016) draws on all of the preceding principles. To these it introduces the idea of resource integration, which we elaborate on next.

While most frameworks from economics focus on resource allocation to maximize profits, strategic management goes well beyond such models and highlights the crucial role of acquiring, protecting, and leveraging VRIN resources to gain competitive advantage. Conceptual work suggests that the effectiveness of the firm's management of its resources, which are purchased, developed, deployed (bundled), and sometimes divested, can explain differences in the performance of the firm relative to others that have similar resources (Sirmon et al., 2007)—and these conclusions have received empirical support (Holcomb, Holmes, \& Connelly, 2009). SDL provides the complementary perspective that firms and individuals are resource integrators in that they combine and align resources (tangible or intangible). The bundling of multiple resources is needed to create capabilities, and the integration of these capabilities is needed to implement a firm's strategy. In turn, the implementation of the strategy in ways that leverage these capabilities creates a competitive advantage. Moreover, how resources are integrated (resource management) can be as influential to the firm's strategic initiatives as the resources alone (Cui, Calantone, \& Griffith, 2011). An implication for SHRM is that HR professionals may be expected to adopt the role of "chief integrative officer: responsible for connecting disparate parts within a company" (Losey, Meisinger, \& Ulrich, 2005, p. 204).

A service perspective is particularly relevant for the integration of resources that are manifested in the talents and efforts of people. Along these lines, guidance for bundling HCR to facilitate strategy implementation may be expressed succinctly as having "the right people to work together on the right things in the right way" (Beer \& Eisenstat, 2000, p. 37). Through its expansive view of relationships, the service perspective provides guidance for how people can effectively work together. We interpret the guidance of deploying the right people in HCR to convey more than simply knowledge, skills, and abilities, but also to include relational capital, which is enhanced with SDL and its emphasis on relationships.

An example of the application of relational capital to resource integration is provided by a service industry study of the influence of middle managers in strategy implementation (Ahearne,
Lam, \& Kraus, 2014). This research showed that middle managers with responsibilities for sales districts were able to leverage their relational capital that was embedded in different business units and regional networks (ecosystems) for strategy implementation. The managers' upward application of reputational capital in these networks enabled them to obtain needed resources and support for strategy adaptation, while their relational capital provided access to information that enabled downward influence in implementation. These arguments illustrate the complexity that an ecosystems view brings to implementation and serve as a reminder of Hrebiniak's (2006) advice not to underestimate the time and personnel requirements for implementation.

Proposition 8: The inclusion of SDO as a criterion for the bundling of HCR facilitates strategy implementation in business ecosystems.

\section{DISCUSSION AND CONCLUSIONS}

The arguments provided suggest that a service perspective can be valuable for managing HCR to more effectively implement a firm's strategy. SDL promotes an interactive process of exchanging service (individuals and firms), thereby encouraging inclusion (participation) and minimizing status differentials (at the individual and unit level). Additionally, SDL encourages trust and knowledge sharing, and all of the attributes noted help build relational capital. Thus, use of SDL in managing HCR facilitates the coordination needed for implementing the firm's strategy through interdependent people, units, and organizations. Such a perspective is particularly relevant in the context of contemporary business environments (at both micro and macro levels) with many interdependencies. These interdependencies exist in business ecosystems in which all types of actors (e.g., suppliers, partners, and customers) must collaborate to create value (Adner, 2006; Adner \& Kapoor, 2016; Kapoor \& Lee, 2013; Normann \& Ramirez, 1993).

The emphasis of a service perspective on building enduring relationships and collaboration provides more nuanced managerial guidance than other approaches such as TCE in producing greater efficiency in the implementation of strategy. A service perspective can help guide collaborative efforts, which have become increasingly important for strategy implementation partly because of the complex combinations of resources. This perspective also 
fosters innovation because of its emphasis on openness, knowledge sharing, and transparency, thus complementing the theoretical guidance for strategy formulation (e.g., the RBV) by providing guidance for strategy implementation.

Using an SDL approach in managing a firm's human capital helps address the three major questions suggested by scholars for strategy implementation. First, it integrates the customer. In fact, it integrates multiple stakeholders and demonstrates how they can collaboratively help the firm realize the value propositions of its strategy. Second, it is interdisciplinary, integrating some of the best thinking in the marketing field with valuable ideas in human resource management and strategic management. Additionally, the SDL draws on concepts from several social sciences such as psychology and sociology. Finally, it is multilevel-including firms, units, and individual employees. And because strategy implementation incorporates the whole organization-all units and all employees-we describe it as multiplex (multilevel and multiunit, making it highly complex).

This work also contributes by extending the work of Becker and Huselid (2006), who argued that human capital plays an important role in the implementation of firm strategy. We have explained how to best manage HCR to implement strategy. The SDL perspective recommended for managing HCR provides a broader perspective than approaches recommended for increasing employee productivity, such as high-performance work systems. The underlying theme of service to others as a touchstone for implementation is relevant for the disciplines of supply chain management and information technology in addition to human resource management and strategic management. As such, it is the first approach that integrates more systems thinking into an approach for implementing strategy that considers the entire business ecosystem.

The research propositions developed and presented in this work provide guidance for future research, but deeper theoretical elaboration is needed. And each of the propositions involves constructs that need to be operationalized across multiple levels, such as trust among individuals and at multiple organizational levels as well as trust between the firm and suppliers or other stakeholders.

This work has several implications for policy. Overall, SDL promotes respect, trust, commitment, and shared mental models. Thus, to prepare for implementation of the firm's strategy, managers must work to ensure that perceptions of respect, trust, commitment, and shared assumptions exist in the firm and throughout the relevant ecosystem. Enduring relationships require care and maintenance, which suggests that the management of HCR is a continuous process requiring support and regular reinforcement. This is especially relevant to ensure customer integration, coordination, and collaboration across multiple levels and multiple units. As we have noted, implementation has sometimes been derailed by socio-emotional issues, such as reduced receptivity resulting from exclusion and insensitivities to perceived status differentials in the organization. An example related to one of the authors by Joe Pichler, former CEO of Kroger, is illustrative of this problem. In a firm that later became a subsidiary of Kroger, there had been continuing problems in implementing a supply chain strategy. Implementation was finally successful, but only after an elegant solution was obtained from lower-level employees whose input had not been previously solicited.

Another policy implication relates to the assessment of performance. For example, thought needs to be given to how to measure the effectiveness of strategy implementation. (What does effectiveness mean?). Also, what are the outcomes desired at the unit, division/SBU, and overall firm levels? Simple accounting measures of performance and even measures of shareholder wealth may not capture the firm's broader performance in satisfying multiple stakeholders and the many participants in the firm's ecosystem. Managers must consider the type of performance needed to ensure the firm's longer-term viability within its business ecosystem.

Another policy implication is the guidance provided by the service perspective for developing the capabilities of the firm's HCR, which in turn facilitate strategy implementation. As strategic initiatives increasingly involve organizational interdependencies and crossorganizational boundaries, skills for managing interfaces at both the individual and firm levels are necessary. As a matter of policy, developing a talent base of T-shaped individuals who have these skills should be a priority for managing HCR to ensure the firm's readiness for ongoing strategy implementation efforts.

Clearly, more conceptual work and evidencebased research need to be on the agenda to extend this work. A sampling of potentially valuable questions to address includes:

- How can we develop a process model of service(s) and service exchange in the implementation process? 
- Can a model of the trust-commitment linkage be developed that fosters implementation?

- How does SDO in implementation influence employee turnover (voluntary and involuntary) and the firm's ability to retain key vendors?

- What are the key drivers of fostering collaborative and co-creation capabilities in the implementation process?

- How can reward systems be designed to foster SDO but also enhance long-term financial performance?

- How can a shared mental model and architecture of participation be fostered in the extended enterprise, and what influence does this have on effective implementation?

- How can institutional theory and institutional logics be used to facilitate our understanding of SDO and strategy implementation?

- What is required to effectively develop T-shaped individuals?

By addressing these questions, we can develop clearer and more complete knowledge of how HCR can be managed to facilitate effective strategy implementation.

Broader research themes demonstrate the complementarity of SDO/SDL with other theoretical approaches. For example, the service perspective is complementary to and supportive of the behavioral theory of the firm (BToF). In fact, Gavetti, Greve, Levinthal, and Ocasio (2012) suggested that the BToF provided a perfect foil for the neoclassical economic model. Its emphasis on performance feedback and organizational learning supplements the service perspective for managing HCR. Future research should focus on how the two theoretical approaches can be integrated to foster more effective strategy implementation. For example, how do the collaboration and knowledge and information exchange promoted by the service perspective for managing HCR promote organizational learning? And how can organizational learning facilitate the strategy implementation process?

Additionally, the integration of managing HCR with strategy implementation can be informed by microfoundations research in strategic management (Felin, Foss, \& Ployhart, 2015). This work integrates knowledge from psychology and organizational behavior with macro-organizational processes. Such knowledge is especially relevant to the motivation of individuals to perform tasks and collaborate with others in interdependent units to implement strategies. In particular, we need to better understand how individuals' identity with the organization and willingness to collaborate can promote more effective strategy implementation.

In conclusion, this work provides several policy implications for managing HCR to more effectively implement the firm's strategy. It also provides the base for much future research on strategy implementation and especially the interrelationships between managing human capital and the implementation of strategies by organizations.

\section{REFERENCES}

Abela, A. V., \& Murphy, P. E. (2008). Marketing with integrity: Ethics and the service-dominant logic for marketing. Journal of the Academy of Marketing Science, 36, 39-53.

Adler, P. S., \& Kwon, S. (2002). Social capital: Prospects for a new concept. Academy of Management Review, 27, 17-40.

Adner, R. (2006). Match your innovation strategy to your innovation ecosystem. Harvard Business Review, 84(4), 98-107.

Adner, R., \& Kapoor, R. (2016). Innovation ecosystems and the pace of substitution: Re-examining technology Scurves. Strategic Management Journal, 37, 625-648.

Ahearne, M., Lam, S. K., \& Kraus, F. (2014). Performance impact of middle managers' adaptive strategy implementation: The role of social capital. Strategic Management Journal, 35, 68-87.

Akaka, M. A., Vargo, S. L., \& Lusch, R. F. (2013). The complexity of context: A service ecosystems approach for international marketing. Journal of International Marketing, 21(4), 1-20.

Argyris, C. (1989). Strategy implementation: An experience in learning. Organizational Dynamics, 18(2), 5-15.

Aryee, S., Walumbwa, F. O., Seidu, E. Y. M., \& Otaye, L. E. (2016). Developing and leveraging human capital resource to promote service quality: Testing a theory of performance. Journal of Management, 42, 480-499.

Baldwin, C. Y., \& Henkel, J. (2015). Modularity and intellectual property protection. Strategic Management Journal, 36, 1637-1655.

Ballantyne, D., \& Varey, R. J. (2006). Introducing a dialogical orientation to the service-dominant logic of marketing. In R. F. Lusch \& S. L. Vargo (Eds.), Servicedominant logic of marketing: Dialog, debate, and directions (pp. 224-244). Armonk, NY: M. E. Sharpe.

Barney, J. (1991). Firm resources and sustained competitive advantage. Journal of Management, 17, 99-120.

Barrick, M. R., Thurgood, G. R., Smith, T. A., \& Courtright, S. H. (2015). Collective organizational engagement: 
Linking motivational antecedents, strategic implementation, and firm performance. Academy of Management Journal, 58, 111-135.

Barrows, E. (2014). What is strategy execution? New York: American Management Association. Retrieved March 25, 2016, from http://www.amanet.org/training/articles/ What-Is-Strategy-Execution.aspx

Becker, B. E., \& Huselid, M. A. (2006). Strategic human resource management: Where do we go from here? Journal of Management, 32, 898-925.

Beer, M., \& Eisenstat, R. A. (2000). The silent killers of strategy implementation and learning. Sloan Management Review, 41(4), 29-40.

Beltran-Martin, I., Roca-Puig, V., Escrig-Tena, A., \& Bou-Llusar, J. C. (2008). Human resource flexibility as a mediating variable between high performance work systems and performance. Journal of Management, 34, 1009-1044.

Berry, L. L. (2000). Cultivating service brand equity. Journal of the Academy of Marketing Science, 28, 128-137.

Bitner, M. J., Ostrom, A. L., \& Morgan, F. N. (2008). Service blueprinting: A practical technique for service innovation. California Management Review, 50(3), 66-94.

Bohling, T., et al. (2006). CRM implementation: Effectiveness issues and insights. Journal of Service Research, 9, 184-194.

Bowen, D. E. (2016). The changing role of employees in service theory and practice: An interdisciplinary view. Human Resource Management Review, 26, 4-14.

Bowen, D. E., \& Ostroff, C. (2004). Understanding HRMperformance linkages: The role of the "strength" of the HRM system. Academy of Management Review, 29, 203-221.

Bowen, D. E., \& Schneider, B. (1988). Services marketing and management: Implications for organizational behavior. In B. M. Staw \& L. L. Cummings (Eds.), Research in organizational behavior (Vol. 10, pp. 43-80). Greenwich, CT: JAI Press.

Bowen, D. E., \& Schneider, B. (2014). A service climate synthesis and future research agenda. Journal of Service Research, 17, 5-22.

Brickson, S. L. (2007). Organizational identity orientation: The genesis of the role of the firm and distinct forms of social value. Academy of Management Review, 32, 864-888.

Cadwallader, S., Jarvis, C. B., Bitner, M. J., \& Ostrom, A. L. (2010). Frontline employee motivation to participate in service innovation implementation. Journal of the Academy of Marketing Science, 38, 219-239.

Chen, M. J., \& Miller, D. (2011). The relational perspective as a business mindset: Managerial implications for East and West. Academy of Management Perspectives, 25(3), 6-18.
Chuang, C., \& Liao, H. (2010). Strategic human resource management context: Taking care of business by taking care of employees and customers. Personnel Psychology, 63, 153-196.

Coase, R. H. (1937). The nature of the firm. Economica, 4, 386-405.

Coff, R., \& Kryscynski, D. (2011). Drilling for microfoundations of human capital-based competitive advantages. Journal of Management, 37, 1429-1443.

Colbert, B. A. (2004). The complex resource-based view: Implications for theory and practice in strategic human resource management. Academy of Management Review, 29, 341-358.

Crook, T. R., Combs, J. G., Ketchen, D. J., Jr., \& Aguinis, H. (2013). Organizing around transaction costs: What have we learned and where do we go from here? Academy of Management Perspectives, 27(1), 63-79.

Cui, A. S., Calantone, R. J., \& Griffith, D. A. (2011). Strategic change and termination of interfirm partnerships. Strategic Management Journal, 32(4), 402-423.

Dalton, D. R., Hitt, M. A., Certo, S. T., \& Dalton, C. M. (2007). The fundamental agency problem and its mitigation: Independence, equity, and the market for corporate control. Academy of Management Annals, 1, 1-64.

Datta, D. K., Guthrie, J. P., \& Wright, P. M. (2005). Human resource management and labor productivity: Does industry matter? Academy of Management Journal, $48,135-145$.

Delery, J. E., \& Doty, D. H. (1996). Modes of theorizing in strategic human resource management: Tests of universalistic, contingency, and configurational performance predictions. Academy of Management Journal, 39, 802-835.

Dutton, J. E., Ashford, S. J., O’Neill, R. M., Hayes, E., \& Wierba, E. E. (1997). Reading the wind: How middle managers assess the context for selling issues to top managers. Strategic Management Journal, 18, 407425.

Dutton, J. E., Ashford, S. J., O’Neill, R. M., \& Lawrence, K. A. (2001). Moves that matter: Issue selling and organizational change. Academy of Management Journal, 44, 716-736.

Dyer, J. H. (2000). Collaborative advantage: Winning through extended enterprise supplier networks. New York: Oxford University Press.

Felin, T., Foss, N. J., \& Ployhart, R. E. (2015). The microfoundations movement in strategy and organization theory. Academy of Management Annals, 9, 575-632.

Finkelstein, S., Hambrick, D. C., \& Cannella, A. A. (2009). Strategic leadership: Theory and research on executives, top management teams, and boards. New York: Oxford University Press. 
Floyd, S. W., \& Woolridge, B. (1992). Middle management involvement in strategy and its association with strategic type: A research note. Strategic Management Journal, 13, 153-167.

Galbraith, J. R. (2002). Organizing to deliver solutions. Organizational Dynamics, 31, 194-207.

Gavetti, G., Greve, H. R., Levinthal, D. A., \& Ocasio, W. (2012). The behavioral theory of the firm: Assessment and prospects. Academy of Management Annals, 9, 1-40.

Ghosh, M., \& John, G. (1999). Governance value analysis and marketing strategy. Journal of Marketing, 63, 131-145.

Ghoshal, S., \& Moran, P. (1996). Bad for practice: A critique of the transaction cost theory. Academy of Management Review, 21, 13-47.

Gibson, C. B., Porath, C. L., Benson, G. S., \& Lawler, E. E., III. (2007). What results when firms implement practices: The differential relationship between specific practices, firm financial performance, customer service, and quality. Journal of Applied Psychology, 92, 14671480.

Gratton, L. (2011). Workplace 2025-what will it look like? Organizational Dynamics, 40, 246-254.

Gratton, L., \& Truss, C. (2003). The three-dimensional people strategy: Putting human resources policies into action. Academy of Management Executive, 17, 7486.

Greer, C. R., Lusch, R. F., \& Vargo, S. L. (2016). A service perspective: Key managerial insights from servicedominant (S-D) logic. Organizational Dynamics, 45(1), 28-38.

Greer, C. R., \& Stevens, C. D. (2015). HR in collaborative innovation with customers: Role, alignment, and challenges. International Journal of Human Resource Management, 26, 2569-2593.

Gremler, D. D., \& Gwinner, K. P. (2000). Customer-employee rapport in service relationships. Journal of Service Research, 3, 82-104.

Guitián, G. (2015). Service as a bridge between ethical principles and business practice: A Catholic social teaching perspective. Journal of Business Ethics, 128, 59-72.

Gulati, R., Lavie, D., \& Singh, H. (2009). The nature of partnering experience and the gains from alliances. Strategic Management Journal, 30, 1213-1233.

Gummesson, E. (2007). Exit services marketing-enter service marketing. Journal of Customer Behaviour, 6, 113-141.

Gutek, B. A., Groth, M., \& Cherry, B. (2002). Achieving service success through relationships and enhanced encounters. Academy of Management Executive, 16(4), 132-144.
Guth, W. D., \& Macmillan, I. C. (1986). Strategy implementation versus middle management self-interest. Strategic Management Journal, 7, 313-327.

Haynes, K. T., Hitt, M. A., \& Campbell, J. (2015). The dark side of leadership: Toward a mid-range theory of hubris and greed in entrepreneurial contexts. Journal of Management Studies, 52, 58-73.

Hickson, D. J., Miller, S. J., \& Wilson, D. C. (2003). Planned or prioritized? Two options in managing the implementation of strategic decisions. Journal of Management Studies, 40, 1803-1836.

Hill, C. W. H., Hitt, M. A., \& Hoskisson, R. E. (1992). Cooperative versus competitive structures in related and unrelated diversified firms. Organization Science, 3, 501-521.

Hitt, M. A., Bierman, L., Shimizu, K., \& Kochhar, R. (2001). Direct and moderating effects of human capital on strategy and performance in professional service firms: A resource-based perspective. Academy of Management Journal, 44, 13-28.

Hitt, M. A., Bierman, L., Uhlenbruck, K., \& Shimizu, K. (2006). The importance of resources in the internationalization of professional service firms: The good, the bad, and the ugly. Academy of Management Journal, 49, 1137-1157.

Hitt, M. A., \& Ireland, R. D. (2002). The essence of strategic leadership: Managing human and social capital. Journal of Leadership \& Organizational Studies, 9, 3-14.

Holcomb, T. T., Holmes, R. M., Jr., \& Connelly, B. L. (2009). Making the most of what you have: Managerial ability as a source of resource value creation. Strategic Management Journal, 30, 457-485.

Hrebiniak, L. G. (2005). Making strategy work. Upper Saddle River, NJ: FT Press-Pearson Education.

Hrebiniak, L. G. (2006). Obstacles to effective strategy implementation. Organizational Dynamics, 35(1), 12-31.

Hunter, S. T., Cushenberry, L., \& Friedrich, T. (2012). Hiring an innovative workforce: A necessary yet uniquely challenging endeavor. Human Resource Management Review, 22, 303-322.

Huy, Q. N. (2011). How middle managers' group-focus emotions and social identities influence strategy implementation. Strategic Management Journal, 32, 1387-1410.

Iansiti, M., \& Levien, R. (2004). Strategy as ecology. Harvard Business Review, 82(3), 68-78.

Jiang, K., Lepak, D. P., Hu, J., \& Baer, J. C. (2012). How does human resource management influence organizational outcomes? A meta-analytic investigation of mediating mechanisms. Academy of Management Journal, 55, 1264-1294. 
Kang, S., Morris, S. S., \& Snell, S. A. (2007). Relational archetypes, organizational learning, and value creation: Extending the human resource architecture. Academy of Management Review, 32, 236-256.

Kanter, R. M. (1994). Collaborative advantage: The art of alliances. Harvard Business Review, 72(4), 96-108.

Kapoor, R., \& Lee, J. M. (2013). Coordinating and competing in ecosystems: How organizational forms shape new technology investments. Strategic Management Journal, 34, 274-296.

Karpen, I. O., Bove, L. L., \& Lukas, B. A. (2012). Linking service-dominant logic and strategic business practice: A conceptual model of service-dominant orientation. Journal of Service Research, 15, 21-38.

Karpen, I. O., Bove, L. L., Lukas, B. A., \& Zyphur, J. J. (2015). Service-dominant orientation: Measurement and impact on performance outcomes. Journal of Retailing, 91, 89-108.

Ketchen, D. J., Jr., Crook, T. R., Todd, S. Y., Combs, J. G., \& Woehr, D. J. (2017). Managing human capital: A metaanalysis of links among human resource practices and systems, human capital, and performance. In M. A. Hitt, S. E. Jackson, S. Carmona, L. Bierman, C. E. Shalley, \& M. Wright (Eds.), The Oxford handbook of strategy implementation (Ch. 10). New York: Oxford University Press.

Knowledge@Wharton. (2005). Three reasons why good strategies fail: Execution, execution ... Retrieved March 25, 2016, from http://knowledge.wharton. upenn.edu/article/three-reasons-why-good-strategiesfail-execution-execution/

Kogut, B., \& Zander, U. (1992). Knowledge of the firm, combinative capabilities, and the replication of technology. Organization Science, 3, 383-397.

Kor, Y. Y., \& Leblebici, H. (2005). How do interdependencies among human-capital deployment, development, and diversification strategies affect firms' financial performance? Strategic Management Journal, 26, 967-985.

Koruna, S. (2004). Leveraging knowledge assets: Combinative capabilities-theory and practice. $R D$ Management, 34, 505-516.

Lamberti, L. (2013). Customer centricity: The construct and the operational antecedents. Journal of Strategic Marketing, 7, 588-612.

Larsson, R., \& Bowen, D. E. (1989). Organization and customer: Managing design and coordination of services. Academy of Management Review, 14, 213-233.

Leana, C. R., \& Van Buren, H. J., III. (1999). Organizational social capital and employment practices. Academy of Management Review, 24, 538-555.

Lee, E., \& Puranam, P. (2016). The implementation imperative: Why one should implement even imperfect strategies perfectly. Strategic Management Journal, 37(8), 1529-1546.

Lepak, D. P., \& Shaw, J. D. (2008). Strategic HRM in North America: Looking to the future. International Journal of Human Resource Management, 19, 1486-1499.

Liao, H., Toya, K., Lepak, D., \& Hong, Y. (2009). Do they see eye to eye? Management and employee perspectives of high-performance work systems and influences on service quality. Journal of Applied Psychology, 94, 371-391.

Losey, M., Meisinger, S. R., \& Ulrich, D. (2005). Conclusion: Reality, impact, and professionalism. Human Resource Management, 44, 201-206.

Love, L. G., Priem, R. L., \& Lumpkin, G. T. (2002). Explicitly articulated strategy and firm performance under alternative levels of centralization. Journal of Management, 28, 611-627.

Lovett, S., Harrison, D., \& Virick, M. (1997). Managing the boundary spanner-customer turnover connection. Human Resource Management Review, 7, 405-424.

Lusch, R. F., \& Nambisan, S. (2015). Service innovation: A service-dominant logic perspective. Management Information Systems Quarterly, 39, 155-175.

Lusch, R. F., \& Vargo, S. L. (2006). Service-dominant logic: Reactions, reflections and refinements. Marketing Theory, 8, 281-288.

Lusch, R. F., \& Vargo, S. L. (2014). Service-dominant logic: Premises, perspectives, possibilities. Cambridge, UK: Cambridge University Press.

Lusch, R. F., Vargo, S. L., \& Malter, A. J. (2006). Marketing as a service-exchange: Taking a leadership role in global marketing management. Organizational Dynamics, 35, 264-278.

Lusch, R. F., Vargo, S. L., \& O’Brien, M. (2007). Competing through service: Insights from service-dominant logic. Journal of Retailing, 83, 5-18.

Lusch, R. F., Vargo, S. L., \& Tanniru, M. (2010). Service value networks and learning. Journal of the Academy of Marketing Science, 38, 19-31.

Lusch, R. F., \& Webster, F. E. (2011). A stakeholderunifying, cocreation philosophy for marketing. Journal of Macromarketing, 31(2), 129-134.

Mantere, S. (2008). Role expectations and middle manager strategic agency. Journal of Management Studies, 45, 294-316.

Marchington, M., Rubery, J., \& Grimshaw, D. (2011). Alignment, integration, and consistency in HRM across multi-employer networks. Human Resource Management, 50, 313-339.

Mars, M. W., Bronstein, J. L., \& Lusch, R. F. (2012). The value of a metaphor: Organizations and ecosystems. Organizational Dynamics, 41, 271-280. 
Martin, J. A., \& Eisenhardt, K. M. (2010). Rewiring: Cross-business-unit collaborations in multibusiness organizations. Academy of Management Journal, 53, 265-301.

Mayer, D. M., Ehrhart, M. G., \& Schneider, B. (2009). Service attribute boundary conditions of the service climate-customer satisfaction link. Academy of Management Journal, 52, 1034-1050.

Mistry, S., Barrick, M., Kirkman, B., \& Hitt, M. A. (2016). TMT strategy implementation processes, teamwork processes and interdependencies (Working Paper). Dallas, TX: Southern Methodist University.

Möller, K., \& Svahn, S. (2006). Role of knowledge in value creation in business nets. Journal of Management Studies, 43, 985-1007.

Morgan, R., \& Hunt, S. D. (1994). The commitment-trust theory of relationship marketing. Journal of Marketing, 58(July), 20-38.

Mossholder, K. W., Richardson, H. A., \& Settoon, R. P. (2011). Human resource systems and helping in organizations: A relational perspective. Academy of Management Review, 36, 33-52.

Narayanan, V. K., Zane, L. J., \& Kemmerer, B. (2011). The cognitive perspective in strategy: An integrative review. Journal of Management, 37, 305-351.

Noble, C. H. (1999). Building the strategy implementation network. Business Horizons, 42, 19-28.

Normann, R., \& Ramirez, R. (1993). From value chain to value constellation: Designing interactive strategy. Harvard Business Review, 71(4), 65-77.

Nutt, P. C. (1999). Surprising but true: Half the decisions in organizations fail. Academy of Management Executive, 13, 75-90.

Nyberg, A. J., \& Wright, P. M. (2015). 50 years of human capital research: Assessing what we know, exploring where we go. Academy of Management Perspectives, 29, 287-295.

Payne, A., \& Frow, P. (2006). Customer relationship management: From strategy to implementation. Journal of Marketing Management, 22, 135-168.

Pinto, J. K., \& Prescott, J. E. (1990). Planning and tactical factors in the project implementation process. Journal of Management Studies, 27, 305-327.

Ployhart, R. E., \& Moliterno, T. P. (2011). Emergence of the human capital resource: A multilevel model. Academy of Management Review, 36, 127-150.

Ployhart, R. E., Nyberg, A. J., Reilly, G., \& Maltarich, M. A. (2014). Human capital is dead; long live human capital resources. Journal of Management, 40, 371-398.

Ployhart, R. E., Weekley, K., \& Ramsey, J. (2009). The consequences of human resource stocks and flows: A longitudinal examination of unit service orientation and unit effectiveness. Academy of Management Journal, 52, 996-1015.
Post, J. E., Preston, L. E., \& Sachs, S. (2002). Managing the extended enterprise: The new stakeholder view. California Management Review, 45(1), 6-28.

Powell, T. C., Lovallo, D., \& Fox, C. R. (2011). Behavioral strategy. Strategic Management Journal, 32, 13691386.

Prahalad, C. K., \& Ramaswamy, V. (2004). The future of competition: Co-creating unique value with customers. Boston: Harvard Business School Press.

Priem, R. L. (2007). A consumer perspective on value creation. Academy of Management Review, 32, 219-235.

Priem, R. L., \& Butler, J. E. (2001). Is the resource-based "view" a useful perspective for strategic management research? Academy of Management Review, 26, 2240 .

Raes, A. M. L., Heijltjes, M. G., Glunk, U., \& Roe, R. A. (2011). The interface of the top management team and middle managers: A process model. Academy of Management Review, 36(1), 102-126.

Rafaeli, A. (1989). When cashiers meet customers: An analysis of the role of supermarket cashiers. Academy of Management Journal, 32, 245-273.

Ramus, T., Vaccaro, A., \& Brusoni, S. (in press). Institutional complexity in turbulent times: Formalization, collaboration and the emergence of blended logics. Academy of Management Journal. doi: 10.5465/ amj.2015.0394.

Rao, A. N., Pearce, J. L., \& Xin, K. (2005). Governments, reciprocal exchange and trust among business associates. International Journal of Business Studies, 36, 104-118.

Reeves, M., Levin, S., \& Ueda, D. (2016). The biology of corporate survival. Harvard Business Review, 94(1), 46-55.

Richey, R. G., Jr., Tokman, M., \& Dalela, V. (2010). Examining collaborative supply chain service technologies: A study of intensity, relationships, and resources. Journal of the Academy of Marketing Science, 38, 71-89.

Rindfleisch, A., \& Heide, J. B. (1997). Transaction cost analysis: Past, present, and future applications. Journal of Marketing, 61, 30-54.

Rust, R. T., \& Chung, T. S. (2006). Marketing models of service and relationships. Marketing Science, 25, 560580.

Sakhartov, A. V., \& Folta, T. B. (2015). Getting beyond relatedness as a driver of corporate value. Strategic Management Journal, 36, 1939-1959.

Schendel, D., \& Hofer, C. (1979). Strategic management: A new view of business policy and planning. Boston: Little, Brown \& Co.

Schneider, B., \& Bowen, D. (1995). Winning the service game. Boston: Harvard Business School Press. 
Schneider, B., White, S. S., \& Paul, M. C. (1998). Linking service climate and customer perceptions of service quality: Test of a causal model. Journal of Applied Psychology, 83, 150-163.

Schoorman, F. D., Mayer, R. C., \& Davis, J. H. (2007). An integrative model of organizational trust: Past, present, and future. Academy of Management Review, 32, 344-354.

Schuler, R. S., Jackson, S. E., \& Tarique, I. (2011). Global talent management and global talent challenges: Strategic opportunities for IHRM. Journal of World Business, 46, 506-516.

Sirmon, D. G., Gove, S., \& Hitt, M. A. (2008). Resource management in dyadic competitive rivalry: The effects of resource bundling and deployment. Academy of Management Journal, 51, 919-935.

Sirmon, D. G., \& Hitt, M. A. (2003). Managing resources: Linking unique resources, management, and wealth creation in family firms. Entrepreneurship Theory and Practice, 27, 339-358.

Sirmon, D. G., \& Hitt, M. A. (2009). Contingencies within dynamic managerial capabilities: Interdependent effects of resource investment and deployment on firm performance. Strategic Management Journal, 30, 1375-1394.

Sirmon, D. G., Hitt, M. A., \& Ireland, R. D. (2007). Managing firm resources in dynamic environments to create value: Looking inside the black box. Academy of Management Review, 32, 273-293.

Smith, B. D. (2009). Maybe I will, maybe I won't: What the connected perspectives of motivation theory and organizational commitment may contribute to our understanding of strategy implementation. Journal of Strategic Marketing, 17, 473-485.

Sull, D., Homkes, R., \& Sull, C. (2015). Why strategy execution unravels-and what to do about it. Harvard Business Review, 93(3), 57-66.

Sullivan, J. J. (1988). Three roles of language in motivation theory. Academy of Management Review, 13, 104115.

Teece, D. J. (2007). Explicating dynamic capabilities: The nature and microfoundations of (sustainable) enterprise performance. Strategic Management Journal, 28, 1319-1350.

Teng, C., \& Barrows, C. W. (2009). Service orientation: Antecedents, outcomes, and implications for hospitality research and practice. Service Industries Journal, 29, 1413-1435.

Trevor, C. O., Reilly, G., \& Gerhart, B. (2012). Reconsidering pay dispersion's effect on the performance of interdependent work: Reconciling sorting and pay inequity. Academy of Management Journal, 55, 585610.
Uzzi, B. (1997). Social structure and competition in interfirm networks: The paradox of embeddedness. Administrative Science Quarterly, 42, 35-67.

Vargo, S. L., \& Lusch, R. F. (2004). Evolving to a new dominant logic for marketing. Journal of Marketing, 68, 1-17.

Vargo, S. L., \& Lusch, R. F. (2008). Service-dominant logic: Continuing the evolution. Journal of the Academy of Marketing Science, 36, 1-10.

Vargo, S. L., \& Lusch, R. F. (2011). It's all B2B ... and beyond: Toward a systems perspective of the market. Industrial Marketing Management, 40, 181-187.

Vargo, S. L., \& Lusch, R. F. (2016). Institutions and axioms: An extension and update of service-dominant logic. Journal of the Academy of Marketing Science, 44, $5-23$.

Vomberg, A., Homburg, C., \& Bornemann, T. (2015). Talented people and strong brands: The contribution of human capital and brand equity to firm value. Strategic Management Journal, 30, 2122-2131.

Webber, S. S., Payne, S. C., \& Taylor, A. B. (2012). Personality and trust fosters service quality. Journal of Business and Psychology, 27, 193-203.

Webster, F. E., \& Lusch, R. F. (2013). Elevating marketing: Marketing is dead! Long live marketing! Journal of the Academy of Marketing Science, 41, 389-399.

White, S., \& Lui, S. S. (2005). Distinguishing costs of cooperation and control in alliances. Strategic Management Journal, 26, 913-932.

Williamson, O. E. (2010). Transaction cost economics: The natural progression. Journal of Retailing, 86, 215-226.

Woolridge, B., \& Floyd, S. W. (1990). The strategy process, middle management involvement, and organizational performance. Strategic Management Journal, 11, 231-241.

Xiao, Z., \& Tsui, A. S. (2007). When brokers may not work: The cultural contingency of social capital in Chinese hightech firms. Administrative Science Quarterly, 52, 1-31.

Youndt, M. A., \& Snell, S. A. (2004). Human resource configurations, intellectual capital, and organizational performance. Academy of Management Perspectives, 16, 337-360.

Zajac, E. J., \& Olson, C. P. (1993). From transaction cost to transaction value analysis: Implications for the study of interorganizational strategies. Journal of Management Studies, 39(1), 131-145.

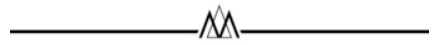

Charles R. (Bob) Greer (c.greer@tcu.edu) is M. J. Neeley Professor of Management in the Neeley School of Business at Texas Christian University. His research interests involve collaborative innovation with customers, staffing 
strategies, human resource implications for innovation, and strategic human resources. He received his Ph.D. from the University of Kansas.

Robert F. Lusch was a marketing professor and Muzzy Chair in Entrepreneurship at the University of Arizona. He served as dean of the College of Business at the University of Oklahoma and the Neeley School of Business at Texas Christian University and was editor of the Journal of Marketing. He was a thought leader in S-D logic along with Stephen Vargo.
Michael A. Hitt (mhitt@mays.tamu.edu; m.a.hitt@tcu.edu) is a University Distinguished Professor Emeritus at Texas A\&M University and a Distinguished Research Fellow at Texas Christian University. He is a former editor of the Academy of Management Journal and the Strategic Entrepreneurship Journal. His current research focuses on international strategy, strategic entrepreneurship, and strategy implementation.

\section{APPENDIX \\ Axioms and Brief Explanations of Service-Dominant Logic}

\section{Axioms of S-D logic}

A1. Service is the fundamental basis of exchange.

A2. Value is co-created by multiple actors, always including the beneficiary.

A3. All social and economic actors are resource integrators.

A4. Value is always uniquely and phenomenologically determined by the beneficiary.

A5. Value co-creation is coordinated through actor-generated institutions and institutional arrangements.

\section{Explanation}

Service (singular) is the application of resources (primarily knowledge and skills) for the benefit of another (or oneself). Service is thus a process. Services (as used in management, marketing, and economics) are focused on intangible units of output. People do not exchange goods or services but exchange specialized applied knowledge and skills; this is often not direct but mediated through organizations, economic currency, and tangible goods (which are distribution mechanisms for service).

Since humans have evolved, they have exchanged service with each other. They are not generalists and rely on many other actors to exist. Thus value is co-created and always includes the beneficiary of the service.

Actors find novel ways to integrate resources drawn from the market and from private and public sources. Each actor thus is a micro-innovator, integrating resources to enhance value co-creation.

Value cannot be added by a firm or even offered by a firm. Firms can only make value propositions, which elaborate on value potential. Only the beneficiary can do the value assessment.

Because actors are resource integrators and value co-creators and have cognitive limits, they need to develop clever solutions to coordinate their activities and behavior. Institutions and institutional arrangements provide that role. 
Copyright of Academy of Management Perspectives is the property of Academy of Management and its content may not be copied or emailed to multiple sites or posted to a listserv without the copyright holder's express written permission. However, users may print, download, or email articles for individual use. 